\title{
FENOMENA MEME HADIS CELANA CINGKRANG DALAM MEDIA SOSIAL
}

\author{
Miski \\ Fakultas Ushuluddin dan Pemikiran Islam UIN Sunan Kalijaga Yogyakarta, Indonesia \\ elbierowy@gmail.com \\ Artikel diterima 31 Oktober, diseleksi 12 November, dan disetujui 8 Desember 2017
}

\begin{abstract}
The objective of this paper is to conduct a deeper study on popular culture, especially that related to meme phenomenon of Hadis forbidding ishbāl (pants above the ankle)) that massively shared in social media. The study begins with an assumption that a phenomenon is not all about creativity and it is not created from an empty space in society. The question here is what is beneath the phenomenon? To answer the question, this study employs the paradigm of constructivism in the framework of discourse analysis; all data are from documented and analyzed by employing the method of content analysis, encompassing exploration process, selection, classification and interpretation. This study demonstrates that in the context of phenomenology of religion, there are at least two main problems in the meme phenomenon of Hadis on ishbāl. Firstly, it is an effort to affirm the identity of various textualist groups among different ideologies in understanding the religion, especially those who tend to be contextualists in understanding the Hadis on isbāl. Secondly, it is a retaliation to various resistance from the common people who understand the Hadis on ishbāl contextually. This finding confirms the existence and relation of the authorities from textualist groups. This is possible as the political condition allows people to give opinion freely and do express various religious practices that are fully strengthened by the easy access to literature directly or via relevant websites.
\end{abstract}

Keywords: Celana Cingkrang, Hadith, Social Media, Meme.

\begin{abstract}
Abstrak
Tulisan ini bermaksud melakukan kajian lebih jauh tentang budaya populer, khususnya terkait fenomena meme hadis celana cingkrang yang bertebaran di media sosial. Berangkat dari paradigma bahwa fenomena tersebut tidak hanya tentang kreativitas dan tidak lahir dari dan dalam ruang kosong di dunia sosial, maka pertanyaannya adalah apa yang ada di balik fenomena tersebut? Untuk menjawab pertanyaan itu, kajian ini menggunakan paradigma konstruktivisme, dengan kerangka analisis wacana; seluruh datanya berbentuk dokumentasi dan dianalisa menggunakan metode konten analisis, yaitu melalui proses eksplorasi, seleksi dan klasifikasi lalu interpretasi. Kajian ini menunjukkan bahwa sebagai fenomena agama, setidaknya terdapat dua persoalan utama di balik fenomena meme hadis celana cingkrang, pertama, merupakan upaya peneguhan identitas keberagamaan kelompok tektualis di tengah kontestasi ideologis antar paham keagamaan, khususnya kelompok yang cenderung kontekstualis dalam memahami hadis-hadis tentang larangan isbāl. Kedua, merupakan salah satu bentuk retaliasi mereka terhadap ragam bentuk resistensi yang dilakukan oleh masyarakat umum yang memahami hadis tentang isbāl tidak secara tekstual. Temuan ini sekaligus menegaskan akan eksistensi dan relasi kuasa kelompok tekstualis seiring kondisi politik yang memungkinkan mereka lebih bebas berpendapat dan mengekspresikan praktik keber-agama-an yang disokong penuh dengan kemudahan mengakses literatur, baik secara langsung maupun melalui website yang dianggap relevan.
\end{abstract}

Kata kunci: Celana Cingkrang, Hadis, Media Sosial, Meme.

Jurnal Multikultural \& Multireligius Vol. 16

No. 2 


\section{PENDAHULUAN}

Fenomena meme, merupakan fenomena yang sedang booming di kalangan pengguna media sosial di Indonesia saat ini, misalnya di twitter, facebook, path dan instagram (Nugraha dkk, 2015: 238). Iqbal Hafizhul L menegaskan bahwa fenomena meme sering kali menggambarkan suatu kejadian yang sedang heboh baik di dunia nyata maupun dunia maya (Hafizhul L: 2017). Salah satu karakteristik media sosial adalah desainnya dalam memudahkan penyebaran pesan dengan teknik publikasi dalam sekala besar serta sangat mudahnya diakses oleh siapa pun. Di samping itu, media sosial juga memiliki kemampuan melahirkan sebuah fenomena baru di kalangan penggunanya maupun khalayak luas, seperti fenomena jilboobs, selfie, meme dan sebagainya (Nugraha dkk, 2015: 238).

Di antara fenomena menarik berkenaan dengan meme adalah adanya meme hadis tentang celana cingkrang yang sangat mudah dijumpai dalam media sosial. Pada kenyataannya sudah banyak kajian yang dilakukan oleh para ahli terkait fenomena meme yang bertebaran di media sosial, antara lain: Aditya Nugraha dkk yang mencoba menelisik fenomena meme di media sosial dengan fokus studi etnografi virtual posting meme pada pengguna media sosial instagram (Nugraha dkk, 2015); Sandy Allifinsyah, menulis tentang korelasi kaum muda, meme, dan demokrasi digital di Indonesia (Allifinsyah, 2016); Rosa Redia Pusanti dan Haryanto menulis tentang representasi kritik dalam meme politik dengan fokus studi semiotika meme politik dalam masa Pemilu 2014 pada jejaring sosial "Path" sebagai media kritik di era siber (Pusanti dan Haryanto, 2014); Natasha Cindy menulis tentang representasi meme jomblo dalam situs jejaring sosial Twitter menggunakan analisis semiotika Roland Barthes) (Cindy,
2016); serta Rendy Pahrun Wadipalapa dengan judul artikel, "Meme Culture \& Komedi-Satire Politik: Kontestasi Pemilihan Presiden dalam Media Baru" (Wadipalapa, 2015). Tulisan lain yang lebih baru dan spesifik tentang meme hadis celana cingkrang adalah tulisan Saifuddin Zuhri Qudsy yang berjudul, "Meme Hadis Celana Cingkrang: Menciptakan Budaya Tanding" (Qudsy, 2017). Dengan demikian dapat diasumsikan bahwa pada dasarnya persoalan ini tidak hanya menarik, melainkan juga penting untuk dianalisa lebih jauh. Pasalnya, meme yang tidak jarang hanya dijadikan media hiburan, pada kenyataannya ada hal lain yang jelas eksis di baliknya.

Namun beberapa kajian yang ada terkait tema ini sama sekali tidak ada yang secara khusus mengkaji persoalan meme hadis celana cingkrang, padahal sebagai sebuah fenomena agama, ia menarik untuk dianalisa lebih jauh bahkan penting dikaji lebih mendalam. Pasalnya ia masuk kategori wacana keagamaan yang dalam banyak kesempatan menjadi wacana yang mendapat perhatian serius dari para ahli terlebih dalam konteks Indonesia; negara dengan populasi muslim terbanyak sehingga mengkaji persoalan agama berarti mengkaji sesuatu yang identik dengan kehidupan mereka. Kalau pun tulisan Saifuddin Zuhri Qudsy memang secara spesifik berkenaan dengan tema meme hadis celana cingkrang, akan tetapi pembahasannya relatif sangat ringkas sehingga tidak banyak memberikan gambaran yang komprehensif. Maka atas pertimbangan tersebut, penulis merasa perlu melakukan kajian terkait tema meme hadis celana cingkrang. Namun, agar lebih spesifik, kajian akan diarahkan untuk menjawab sebuah pertanyaan: ada apa di balik fenomena meme hadis celana cingkrang? Pertanyaan tersebut guna berkenaan dengan motif dan kepentingan yang tersembunyi di baliknya. 
Pada kajian ini, dunia maya, yang diasosiasikan dengan media sosial, diperlakukan secara sama dengan dunia nyata. Mengingat sifatnya yang sama, maka ia bisa didekati dengan seperangkat metodologi yang bisa diaplikasikan pada masyarakat di dunia nyata (Rachman, 2017: 209). Lebih jauh Indrajit mengatakan bahwa dengan saling berhimpitnya dunia maya dengan dunia nyata, maka dapat dipastikan akan terjadi hubungan yang saling berkaitan erat dan saling memngaruhi antar keduanya dan pada gilirannya akan saling menyatu dan identik (Indrajit, t.th).

\section{METODE}

Dalam menganalisa tema di atas, artikel ini menggunakan paradigma konstruktivisme, yaitu dengan meletakkan posisi meme hadis celana cingkrang sebagai sesutu yang sudah diatur oleh si pembuat meme melalui kata-kata dan memiliki tujuan sekaligus sebagai upaya mengungkap jati diri. Secara spesifik, kerangka yang digunakan ialah analisis wacana yang dimaksudkan untuk membongkar maksud dan makna tertentu yang ada di balik fenomena meme yang menjadi fokus kajian. Upaya menmbongkar maksud dan makna tersebut salah satunya dilakukan dengan melihat struktur dan alur pesan yang disampaikan.

Seluruh data meme berbentuk dokumentasi dan dianalisa menggunakan metode konten analisis, yaitu melalui proses eksplorasi; melalui proses ini, penulis akan melakukan penelusuran labih jauh tentang bentuk, model dan pesan meme hadis celana cingkrang yang terdapat di media sosial. Secara operasional, dalam rangka menjaring meme hadis celana cingkrang, penulis menggunakan kata kunci; celana cingkrang, celana ngatung, celana isbal dan sebagainya. Berikutnya, proses seleksi dan klasifikasi, yakni setelah mendapatkan beragam meme hadis, penulis kemudian melakukan seleksi, dengan mendahulukan meme yang dinilai paling relevan, kemudian melakukan klasifikasi, yaitu membagi meme tersebut pada beberapa kriteria tertentu seperti berdasarkan isi dan pesan yang terkandung di dalamnya; berikutnya penulis melakukan interpretasi terhadap meme yang berhasil diklasifikasi.

\section{PEMBAHASAN}

\section{Produksi Meme: Kecenderungan Baru dalam Bermedia Sosial}

Media sosial (social networking) adalah media online dengan para pengguna yang dengan mudah berpartisipasi, berbagi, menciptakan isi, meliputi blog, wiki, forum dan sebagainya. Bisa juga didefinisikan sebagai media online yang mendukung interaksi dan media sosial dengan menggunakan teknologi berbasis web, dari gaya komunikasi menjadi dialog interaktif. Hal ini sekaligus karakter pembeda antara media tradisional dengan media sosial; media tradisional menggunakan media cetak dan media broadcast sedangkan media sosial menggunakan internet. Selain itu, media sosial mengajak siapa pun yang tertarik untukikutberpartisipasi dan berkontribusi serta feedback secara terbuka, memberikan komentar serta membagi informasi kapan pun dengan sangat cepat dan tanpa batas (Putri dkk: 50). Demikianlah, tidak bisa dipungkiri bahwa internet, sejak kemunculannya, telah memberikan gairah baru dalam berkomunikasi. Gairah baru tersebut dirasakan oleh masyarakat seiring kecepatan dan daya sebarnya yang luas sehingga semakin digemari. Tidak mengherankan, ia pun dipilih menjadi sarana penyampai informasi atau apa pun oleh berbagai pihak. Sarana penyampai 
informasi tersebut pada dekade terakhir spesifik menggunakan medium meme (Allifinsyah, 2016: 152).

Kata meme berasal dari bahasa Yunani yang berarti tiruan. Ia kali pertama diperkenalkan oleh seorang biolog asal Britania Raya, Richard Dawkins, sekitar 1970. Dia menganalogikan meme sebagai gen yang dikenal luas dalam istilah biologi. Dia beranggapan bahwa meme tidak berbeda jauh dengan gene; jika gene digunakan untuk menjelaskan evolusi biologis, meme digunakan untuk menjelaskan evolusi kebudayaan, yang meliputi segala sesuatu yang kita pelajari melalui imitasi, termasuk kosa kata, legenda, lagu, peraturan, ucapan populer, mode, busana dan lain-lain (Hukmi, t.th: 6-8). Dengan kata lain, dalam konteks budaya, meme menjadi sebentuk transmisi budaya melalui proses replikasi ide dan gagasan yang masuk ke dalam dunia kognitif umat manusia. Konsep inilah yang kemudian diaplikasikan dalam konteks meme yang terdapat dalam media sosial (Allifinsyah, 2016: 153). Dalam hal ini, meme di internet dapat dipahami sebagai sebentuk replikasi seperti gambar, video dan semacamnya meskipun dalam istilah yang populer dipakai dan dipahami secara umum ia merupakan replikasi gambar yang diberi tautan teks yang bersifat kontekstual sesuai topik yang dimaksudkan (Allifinsyah, 2016: 153; Pusanti dan Haryanto, 2014: 8).

Gambar yang dijadikan meme pada dasarnya merupakan bentuk ekspresi yang disampaikan oleh seseorang melalui gambar-gambar. Tidak jarang ia terus berkembang melalui komentar, parodi, imitasi atau hasil pemberitaan di media sosial, meskipun pada praktiknya ia tidak hanya hadir sebagai parodi atau lelucon saja tetapi menjadi gaya komunikasi baru yang mampu mengandung muatan politik bahkan sarana melakukan kritik terhadap elite negara. Ia juga tidak hanya peniruan, imitasi dan murni kreativitas tanpa maksud dan tujuan, melainkan ia dibuat, dimodifikasi dan diberimakna sedemikian rupa. Pada gilirannya ia pun menjadi salah satu indikator budaya masyarakat aktif digital sehingga selalu relevan untuk kajian yang berhubungan dengan partisipasi masyarakat (Cindy, 2016: 3; Allifinsyah, 2016: 152; Nugraha, 2014: 238; Wadipalapa, Pusanti dan Haryanto, 2014: 8).

Dalam konteks Indoensia, belum ada kajian yang memastikan kapan meme muncul untuk pertama kalinya, meski pun diyakini, meme menjadi bagian yang integral dengan yang internet. Menurut Sandy Allifinsyah, apabila mengacu pada kemunculan meme secara global, maka replikasi gambar seperti yang disinggung di atas sudah mulai muncul pada 2009 silam. Bermula dari Ducreux yang melukis dirinya sendiri pada 1793 namun kamudian hasil lukisan tersebut (gambar) mereplikasi diri di internet dengan penambahan-penambahan caption, berisi kutipan-kutipan syair, lagu atau bahkan sindiran-sindiran kepada sebuah gaya hidup mapan. Caption tersebut hadir dalam kalimat parodi. Hal inilah yang kemudian populer disebut meme lalu menyebar sedemikian cepat dan mereplikasi diri menjadi versiversi yang bersifat kontekstual sesuai dengan topik yang muncul saat itu. Dengan mengutip Yun, Sandy Allifinsyah menyebutkan, bahwa meme merupakan sebuah unexpected connections antara teks dan gambar yang tersaji dan bersifat integral antar keduanya, sehingga apabila kedua unsur dihilangkan, maka maksud dari meme juga akan hilang. Lebih jauh dia mengatakan bahwa dalam konteks di Indonesia, istilah meme ini populer melalui situs yeahmahasiswa.com pada 2009 silam yang menunjuk pada berbagai meme berisi parodi dan sindiran kehidupan keseharian mahasiswa, mulai dari persoalan skripsi, tugas akhir hingga indeks prestasi kumulatif. Fenomena ini pun kemudian berkembang ke arah 
yang lebih luas dan bereplikasi menjadi beragam variasi yang membahas berbagai topik kemudian menyebar melalui jejaring sosial maupun situs-situs yang terdapat di internet (Allifinsyah, 2016: 153).

\section{Hadis, Celana Cingkrang dan Meme Hadis Celana Cingkrang di Media Sosial}

Beberapahaldiatas dapat dipastikan berlaku pula untuk meme hadis celana cingkrang yakni yang belum diketahui kapan kali pertama kemunculannya serta adanya komponen teks dan gambar yang musti harus melekat, yang dalam hal ini menjadi objek kajian. Hadis secara etimologi berarti sesuatu yang baru sebagai lawan dari kata 'lama' -, berita, pembicaraan dan sejenisnya. Secara terminologi, hadis berarti segala sesuatu yang disandarkan kepada Nabi, baik berupa perkataan, perbuatan maupun diamnya beliau terkait peristiwa tertentu yang beliau saksikan (taqrīr, ketetapan) (Ibn Man ūr, 1414 H, II: 133; al- āli , 1977: 3-5; al-'Asqalān̄̄, 1379 H, I: 193). Sedangkan celana cingkrang atau dalam bahasa yang lain disebut celana nggantung berarti sebuah pakaian yang sudah jamak diketahui oleh masyarakat pada umumnya, yaitu pakaian tubuh bagian bawah khususnya bagian pusar sampai kaki dengan model tertentu termasuk berbeda dengan model sarung maupun rok; istilah cingkrang digunakan untuk menunjuk pada pakaian yang biasanya tidak sampai menutupi seluruh kaki, misalnya hanya sampai pertengahan betis atau sedikit lebih tinggi dari mata kaki, namun tidak sampai setinggi lutut. Terminologi ini merupakan bentuk terbalik dari istilah isbāl yang biasa dipakai dalam bahasa Agama (baca: hadis). Isbāl, secara sederhana merujuk pada definisi menurunkan, memanjangkan atau membentangkan pakaian sampai melewati mata kaki. Istilah ini semakna dengan kata jarra, madda dan asfala yang dikenal luas dalam studi hadis (Nasir, Muhammad, 2013: 82). Dengan demikian, secara definitif-konseptual, meme hadis celana cingkrang mengacu pada bentuk integral dari dua komponen inti: hadis tertulis dan gambar celana cingkrang.

Dalam penelusuran lebih jauh dalam berbagai media sosial, meme hadis tersebut lahir dengan beberapa tipe dan model; antara lain:

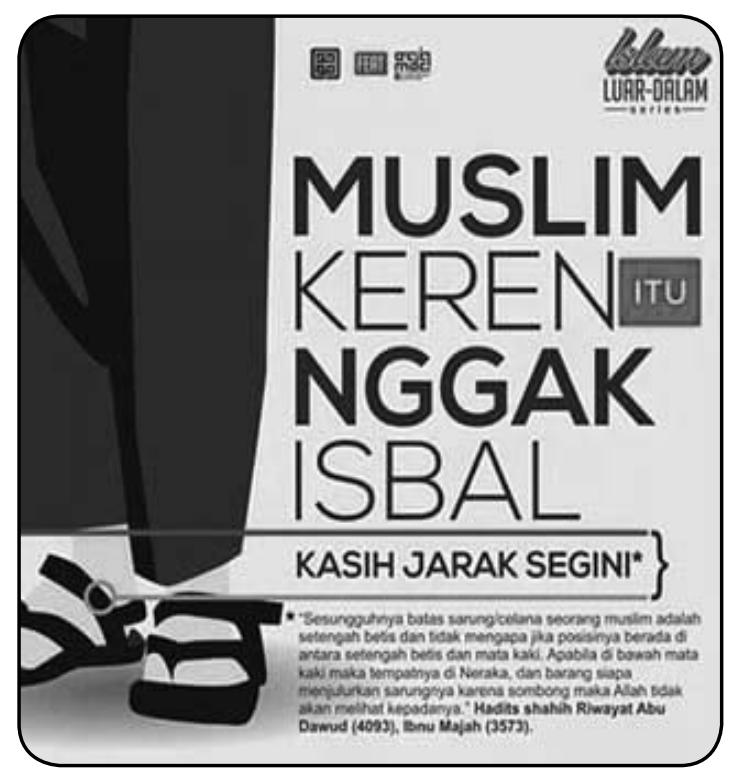

Gambar 1: Muslim keren itu nggak isbal (sugiheling.net, 2017)

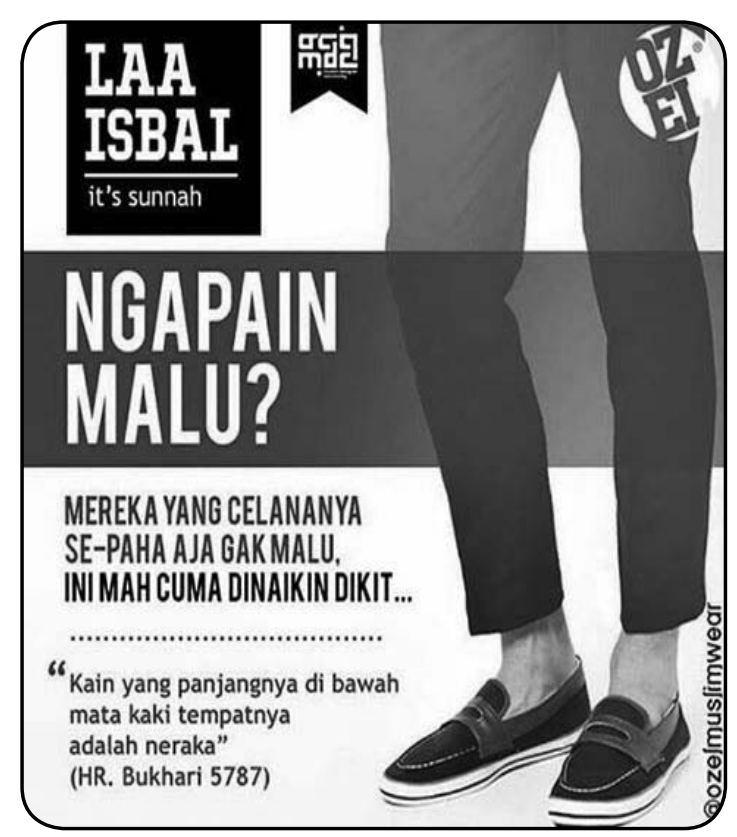

Gambar 2: Ngapain malu? (imgrum.org 2017) 
Gambar pertama (1) dan kedua (2) menunjukkan celana dengan ujung di atas mata kaki. Keduanya memuat pesan tentang larangan isbal dengan deskripsi dan narasi yang sedikit berbedaa. Gambar pertama memuat keterangan:

Muslim keren itu nggak isbal. Kasih jarak segini (Panah menujuk batasan bawah ujung celana). "Sesungguhnya batas sarung/celana seorang muslim adalah setengah betis dan tidak mengapa jika posisinya berada di antara setengah betis dan mata kaki. Apabila di bawah mata kaki, maka tempatnya di neraka, dan barangsiapa menjulurkan sarungnya karena sombong, maka Allah tidak akan melihat kepadanya. Hadis sahih riwayat Abu Dawud 4093, Ibn Majah 3572.

Sedangkan gambar kedua memuat narasi, "Ngapain malu? Mereka yang celananya sepaha aja gak malu, ini cuma dinaikin dikit... 'Kain yang panjangnya di bawah mata kaki tempatnya adalah neraka.' HR. Bukhari 5787."

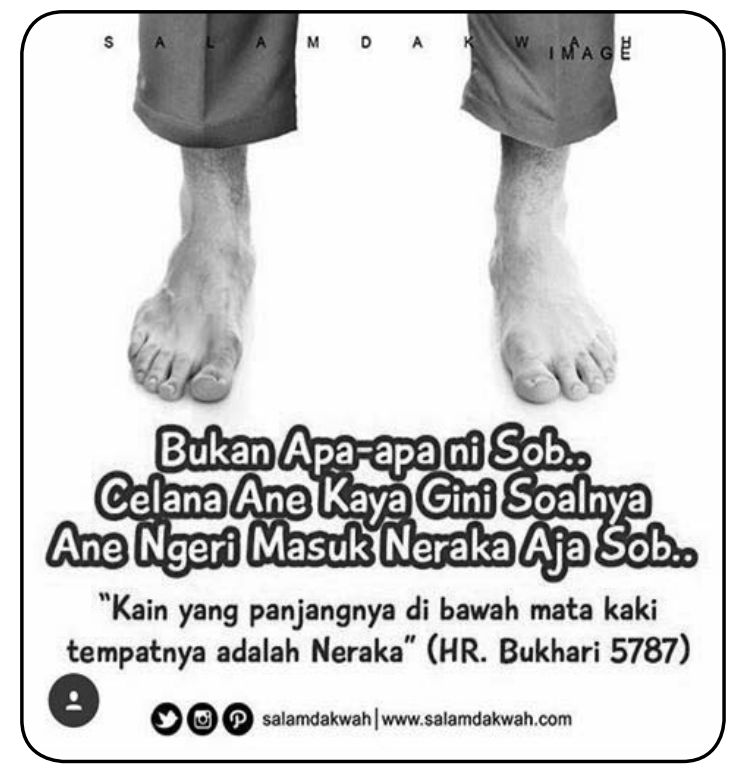

Gambar 3: Bukan apa-apa sih Sob.. Celana ane kaya gini soalnya ane ngeri masuk neraka aja sob (imgrum.co, 2017)

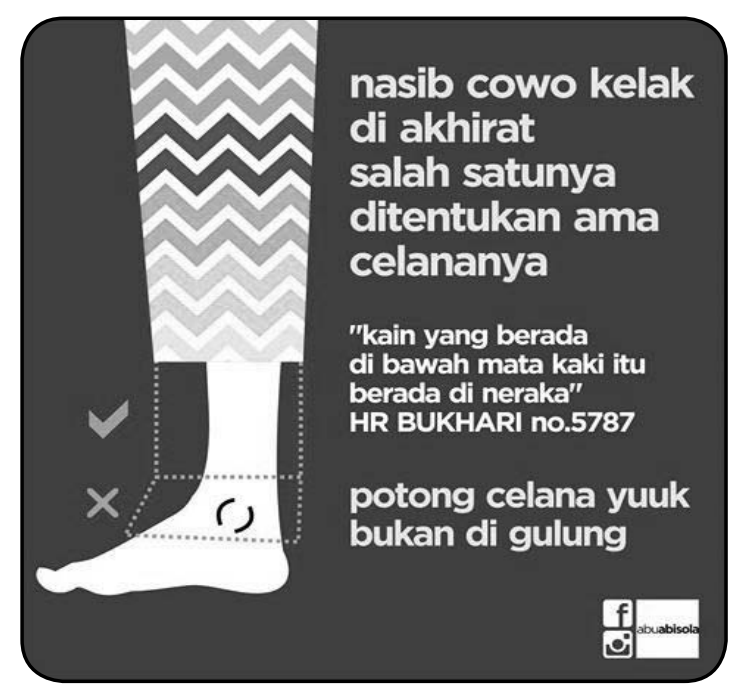

Gambar 4: Nasib cowok kelak di akhirat salah satunya ditentukan ama celananya (mui-jakartatimur.or.id, 2017)

Gambar ketiga (3) dan keempat (4) tidak jauh berbeda dengan dua gambar sebelumnya; tentang larangan isbal. Perbedaan yang paling mencolok adalah pada bagian keterangan yang disematkan pada masing-masing meme; gambar ketiga (3) memuat keterangan: "Bukan apa-apa sih Sob.. Celana ane kaya gini soalnya ane ngeri masuk neraka aja sob.. "Kain yang panjangnya di bawah mata kaki, tempatnya adalah neraka. HR. Bukhari, 5787." Sedangkan pada gambar keempat (4) memuat keterangan: "Nasib cowok kelak di akhirat salah satunya ditentukan ama celananya. "Kain yang berada di bawah mata kaki itu berada di neraka. HR. Bukhari, 5787.' Potong celana yuuk, bukan digulung."

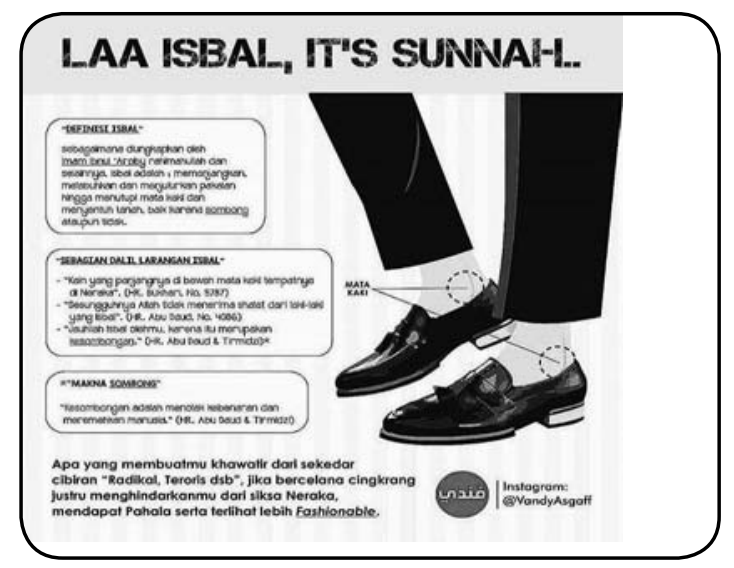

Gambar 5: Laa isbal, it's sunnah (imgrum.co, 2017) 


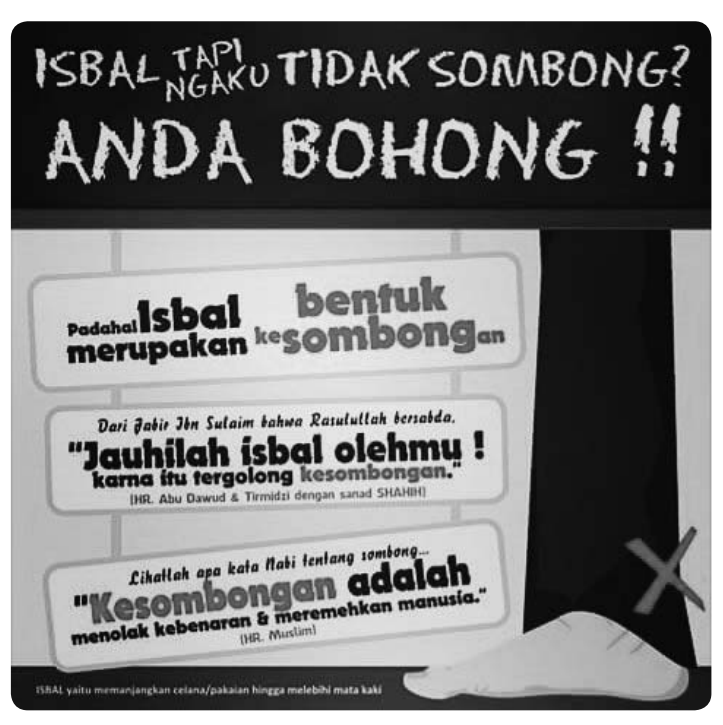

Gambar 6: Isbal tapi ngaku tidak sombong? Anda bohong!! (imgrum.co, 2017)

Pada gambar kelima (5) di atas terdapat sebuah keterangan:

Laa isbal, it's sunnah. Definisi isbal sebagaimana diungkapkan oleh imam Ibnul 'Araby rahimahullah dan selainnya, isbal adalah: memanjangkan, melabuhkan dan menjulurkan pakaian hingga menutupi mata kaki dan menyentuh tanah, baik karena sombong atau pun tidak. "Sebagian dalil larangan isbal; Kain yang panjangnya di bawah mata kaki tempatnya di neraka. (HR. Bukhari no. 5787); "Sesungguhnya Allah tidak menerima shalat dari laki-laki yang isbal." (HR. Abu Dawud, nor. 4086); "Jauhilah isbal olehmu, karena itu merupakan kesombongan." HR. Abu Dawud dan Tirmidzi). Makna sombong: "Kesombongan adalah menolak kebenaran dan meremehkan manusia." (HR. Abu Dawud dan Tirmidzi).

Sebagai ungkapan penutup meme tersebut diberi penegasan: "Apa yang membuatmukhawatir dari sekedar cibiran "radikal, teroris dsb," jika bercelana cinkrang justru menghindarkanmu dari siksa Neraka, mendapat pahala serta terlihat lebih fashionable.

Pada gambar keenam (6) terdapat keterangan:

"Isbal tapi ngaku tidak sombong? Anda bohong!! Padahal isbal merupakan bentuk kesombongan. Dari Jabir bin Sulaim bahwa Rasulullah bersabda, "Jauhilah isbal olehmu! Karena itu tergolong kesombongan." HR. Abu Dawud \&Tirmidzi dengan sanad sahih. Lihatlah apa kata Nabi tentang sombong, "Kesombongan adalah menolak kebenaran dan meremehkan manusia." HR. Muslim. Isbal yaitu memanjangkan celana hingga mata kaki.

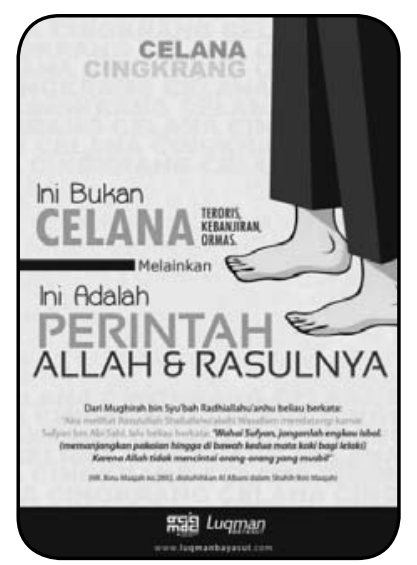

Gambar 7: Celana cingkrang. Ini bukan celana teroris, kebanjiran, ormas (plus. google.com, 2017)

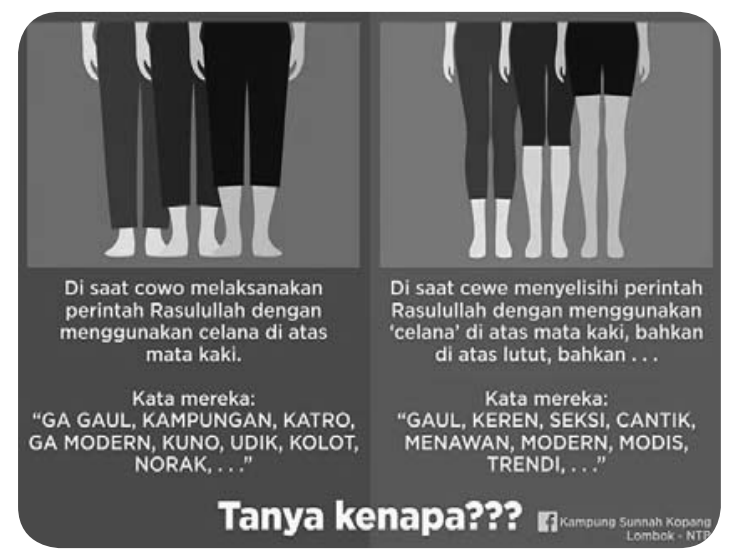

Gambar 8: Di saat cowok melaksanakan perintah Rasulullah dengan celana di atas mata kaki (instagram.com, 2017)

\begin{tabular}{l|l} 
Jurnal Multikultural \& Multireligius Vol. 16 & No. 2
\end{tabular} 
Tidak jauh berbeda dengan beberapa gambar yang sudah disebutkan dengan muatan pesan tentang larangan isbal, gambar ketujuh (7) ini pun demikian adanya. Perbedaannya hanya pada keterangan yang dimuat di dalamnya:

Celana cingkrang. Ini bukan celana teroris, kebanjiran, ormas. Melainkan ini adalah perintah Allah dan rasul-Nya. Dari Mughirah bin Syu'bah radhiyallahu'anhu beliau berkata: Aku melihat Rasulullah shallahu 'alaihi wa sallam mendatangi Sufyan bin Abi Sahl, lalu beliau berkata: Wahai Sufyan, janganlah engkau isbal (memanjangkan pakaian hingga di bawah kedua mata kaki bagi lelaki). Karena Allah tidak mencintai orang-orang yang musbil. HR. Ibnu Majah, 2892, disahihkan al-Albani dalam Shahih Ibnu Majah.

Sedangkan keterangan pada gambar kedelapan (8) memuat pesan:

Di saat cowok melaksanakan perintah Rasulullah dengan celana di atas mata kaki. Kata mereka: GA GAUL, KAMPUNGAN, KATRO, GA MODERN, KUNO, UDIK, KOLOT, NORAK,....." Di saat cewek menyelisihi perintah Rasulullah dengan menggunakan celana di atas mata kaki, bahkan di atas lutut, bahkan... kata mereka: GAUL, KEREN, SEKSI, CANTIK, MENAWAN, MODERN, MODIS, TRENDI..." Tanya kenapa???"

Beberapa meme di atas hanya sebagian dari sekian banyak meme yang memuat tema dan konten yang sama yang bertebaran di media sosial. Namun, bisa dipastikan bahwa meme yang sudah penulis sebutkan atau yang tidak penulis sebutkan tidak lebih dari sekedar replikasi dan imitasi dari satu meme menjadi beberapa meme, sebuah karakter yang biasanya melekat pada seluruh model meme yang ada. Dikatakan hanya replikasi dan reproduksi karena pada kenyataannya dalam koteks hadis yang dijadikan acuan nyaris seragam dan terbatas pada teks hadis tertentu saja, seperti teks tertentu yang terdapat dalam

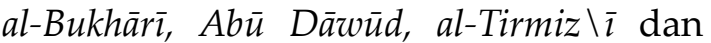
Ibn Mājah. Selain itu, muatan pesan yang dikandung di dalamnya pun yang nyaris sama, yaitu tentang larangan isbāl.

\section{Meme Hadis Celana Cingkrang: dari Peneguhan Identitas Sosial di tengah Kontestasi Ideologis hingga Retaliasi terhadap Resistensi Kelompok Mayoritas}

Berdasarkan terminologi isbāl pada paparan terdahulu, maka seseorang dikatakan melakukan perbuatan isbāl (Arab: musbil) saat dia menjulurkan pakaian melewati mata kaki -atau bahkan- hingga menyentuh tanah. Hal ini sekaligus sebagai bentuk penegasan bahwa pada dasarnya persoalan isbāl tidak terbatas pada persoalan celana. Melainkan pada pakaian model dan jenis apa pun, seperti sarung, jubah dan sebagainya (Abū Zaid, 1416 H: 18; al-San'ānī, 1992: 25; Nasir, 2013: 82; Amran, 2016). Kalau pun di dalam beberapa hadis yang ada menyebutkan jenis pakaian tertentu sarung, misalnya- ia hanya contoh yang bersifat sosiologis dari sebuah pakaian yang biasa dikenakan oleh masyarakat Arab waktu itu (al-Bassām, 1992, VI: 246; (Abū Zaid, 1416 H: 18).

Bakar 'Abd Allāh Abū Zaid menegaskan bahwa hadis tentang larangan isbāl secara maknawi sudah sampai pada taraf mutawatir; disebutkan dalam berbagai literatur dan diriwayatkan dari banyak jalur sanad dari para sahabat Nabi, seperti 'Abd Allāh ibn 'Abbās, Ibn 'Umar, Ibn Mas' ùd, Abū Hurairah, Anas, Abū Żarr, 'A' 'isyah, Hubaib ibn alMugaffal al-Ansārī, Abū Sa'īd al-Ansārī, Khużaifah ibn al-Yamān, al-Mugīrah ibn Syu'bah, Samurah ibn Jundub, Sufyan ibn 
Sahl, Abū Umāmah, 'Ubaid ibn Khālid, Jābir ibn Sulaim, Ibn al- an aliyyah, 'Amr ibn Syarīd dan lain-lain (Abū Zaid, 1416 H: 18). Tidak hanya itu, pembahasan ini pun menjadi pembahasan yang relatif vital dalam kajian para ahli terdahulu. Terbukti dengan masuknya pembahasan tentang isbāl dalam karya-karya besar mereka.

Jadi, istilah celana cingkrang, celana ngatung dan sejenisnya dalam konteks meme di atas -yang disebut sesuai dengan sunah- dinilai sebagai bentuk antitesis dari istilah isbāl yang diyakini terlarang berdasarkan pemahaman mereka terhadap teks hadis Nabi. Sampai pada poin ini tampak bagaimana para produser meme hadis celana cingkrang melakukan reaktualisasi masalah isbāl dengan banyak memberikan ilustrasi celana, bukan sarung dan sebagainya. Hal ini dapat dipahami dengan kenyataan lain bahwa dalam konteks Indonesia, celana lebih banyak diminati oleh para lelaki sebagai pakaian yang lebih fleksibel digunakan dalam beragam acara, terlebih di wilayah perkotaan; wilayah yang memiliki waktu lebih luang untuk bermedia sosial. Sehingga penggunaan ilustrasi celana pada meme di atas mestinya lebih efisien dan relevan apabila dimaksudkan untuk sosialisasi hadis tersebut.

Berbicaratentangmodelpembacaan, teknik interpretasi dan tipologi pemahaman hadis Nabi, secara garis besar terdapat dua kategori: tekstual dan kontekstual. Pembacaan tekstual berarti pembacaan terhadap teks hadis Nabi tanpa memedulikan aspek kesejarahan yang mengitarinya. Penganut model ini biasa disebut tektualis, skriptualis atau literalis. Sedangkan pembacaan kontekstual berarti pembacaan kritis dengan mempertimbangkan berbagai aspek yang mengitari lahirnya teks hadis ( $a s b \bar{a} b$ al-wurūd) dan sebagainya. Penganut model ini biasanya disebut dengan kelompok kontekstualis (Aw, 2011: 395; Asriaty, 2013: 2; Abu Nawas, 2015: 100).
Memperhatikan beberapa meme yang sudah disebutkan di atas tampaknya pembacaan, teknik interpretasi dan tipologi pemahaman yang digunakan oleh produser meme celana cingkrang yang bertebaran di media sosial lebih tepat apabila disebut tekstualis. Teks-teks hadis yang dijadikan sandaran meskipun tidak tunggal, akan tetapi semuanya dipahami dengan satu pemahaman: isbāl tetap haram. Menjulurkan pakaian melebihi mata kaki akan dinilai berdosa.

Sudut pandang ini berbeda dengan mayoritas ulama, yang cenderung tampak lebih kontekstual, yang menegaskan bahwa larangan isbāl dalam pengertian haram- hanya apabila disertai adanya perasaan sombong. Apabila tidak demikian, hukumnya boleh atau makruh. Ilustrasi yang dipaparkan pada meme cenderung bertumpu pada bunyi teks tanpa upaya mendalami segala kemungkinan yang berada di luar teks, seperti kemungkinan kondisi ekonomi yang senjang, misalnya, untuk membeli kain pun masih sulit, sehingga memanjangkan kain hingga melewati mata kaki bisa memperuncing dan semakin menjauhkan sekat antar si kaya dengan si miskin; termasuk kemungkinan lain yang berada di dalam maupun di luar teks itu sendiri.

Dengan mengacu pada paparan dan meme di atas, setidaknya terdapat dua titik penting yang berada di balik fenomena tersebut, pertama, bahwa ia merupakan media peneguhan identitas diri kelompok tektualis, skriptualis atau literalis. Peneguhan tersebut diekspresikan dengan cara melakukan identifikasi diri sebagai kelompok yang mengikuti sunah Nabi Saw. meski pun pada dasarnya hanya berangkat dari sebuah pemahaman tekstual terhadap teks-teks agama, khususnya teks hadis seputar isbāl, sebagai sebuah pemahaman yang relatif berbeda dengan mereka yang cenderung lebih kontekstual, seperti pemahaman mayoritas ulama. 
Peneguhan identitas ini tidak bisa dipungkiri sudah mengalami transformasi atau bahkan pergeseran dari generasi sebelumnya, terutama abad pertengahan Islam. Pada waktu itu identitas sosial -khususnya keagamaanmelekat dan berkorelasi kuat dengan kelompok mazhab fikih; perdebatanperdebatan tentang wacana keagamaan selalu identik dengan perbedaan antar kelompok satu mazhab dengan mazab yang lain. Hal ini tanpa terkecuali terkait persoalan isbāl yang melahirkan tiga pendapat di kalangan ulama: haram, makruh dan boleh. Dua pendapat yang terakhir merupakan pendapat yang dipilih oleh mayoritas penganut mazhab Maliki, Hanafi Syafii dan Hanbali. Tokohtokoh besar mereka antara lain: Abū Hanīfah dari mazhab Hanafi (pendiri), al-Hattāb dari mazhab Maliki, al-Nawawī dari mazhab Syafii, Ibn Qudāmah dari mazhab Hanbali, Ibn Taimiyah dari mazhab Hanbali dan lain-lain. Bagi mayoritas ulama, alasan ('llah) pelarangan isbāl adalah kesombongan sehingga apabila alasan 'illah tersebut hilang maka secara otomatis larangan pun hilang. 'Abd Allāh al-Bassām salah satu tokoh yang mencoba menjelaskan logika mayoritas ulama terkait persoalan isbāl menulis (alBassām, 1992, VI: 246):

...ووإذا نظرنا إلى عموم اللباس وهيئاته وإشكاله لم بند منه

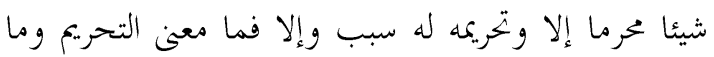

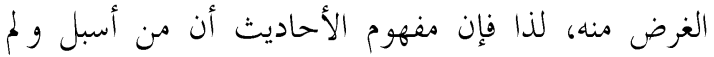

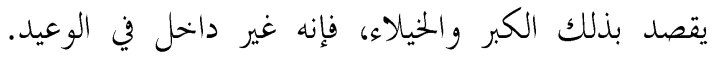

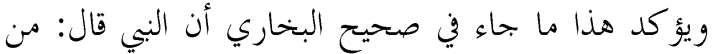

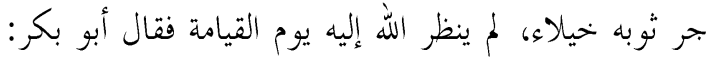

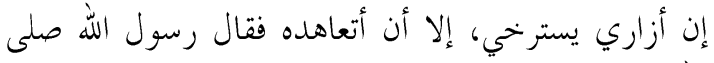

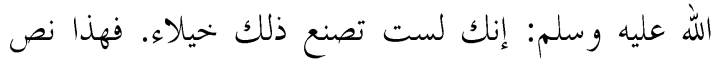
صحيح صريح في المسألة في أن القصد من التحريم هو الخيلاء لا كثرة نزول الإزار أو قلته وإلا لقيده به...

Jika kita memperhatikan aturan umum terkait pakaian dengan semua jenis dan modelnya, kita tidak mendapati aturan pengharaman kecuali karena sebab tertentu, apabila tidak karena demikian, lalu apa maksud dan tujuan dari aturan pengharaman tersebut. Maka dari itu, pemahaman terhadap hadis-hadis terkait adalah bahwa barangsiapa isbāl akan tetapi tidak bermaksud sombong maka dia tidak termasuk mereka yang mendapatkan ancaman. Hal ini dikuatkan oleh sebuah riwayat yang terdapat dalam Sahih al-Bukhārī bahwasanya Nabi Saw. bersabda: "Barangsiapa menjulurkan pakaiannya karena sombong, maka Allah tidak akan melihatnya pada hari Kiamat." Lalu Abū Bakr berkata, "Sarungku biasa melorot kecuali kalau aku mengikatnya." Rasulullah pun menjawabnya, "Kamu tidak melakukan itu karena sombong." Ini tepat dan jelas terkait persoalan ini bahwa pengharaman isbāl berkonotasi dengan kesombongan bukan karena kain sarung yang terlalu panjang atau terlalu pendek; jika persoalannya memang karena hal tersebut niscaya ada pembatasan tertentu.

Sedangkan ulama lain yang memilih mengharamkan, antara lain: Ibn al-'Arabī, al-Qarafì, IbnH Hajar al-'Asqalāni, al-Żahabī, al-San'ānì dan lain-lain, serta menjadi pendapat yang dipilih oleh mayoritas ulama Timur Tengah seperti Ibn Bāz, Ibn 'Usaimīn, Ibn Jibrīn, al-Fauzān dan sebagainya. Tentunya dengan argumen tekstual yang dianggap menguatkan pendapat mereka (islamqa.info, 2017; Abū Zaid, 1416 H: 18; al-Bassām, 1992, VI: 246). Pada gilirannya, dalam konteks hari ini, sekali lagi, perdebatan tersebut tidak lagi diarahkan pada perdebatan antar satu kelompok fikih dengan kelompok fikih yang lain, melainkan sudah bergeser pada perdebatan antar kelompok yang mengidentifikasikan diri sebagai kelompok yang mengikuti sunah Nabi dengan kelompok yang menurut mereka tidak sesuai sunah. Terlepas dari kenyataan bahwa sebenarnya 
titik persoalannya hanya pada pilihan memahami hadis-hadis terkait secara tekstual ataukah secara kontekstual.

Kedua, sebagai bentuk retaliasi kelompok tekstualis -sebagai minoritasterhadap ragam resistensi masyarakat yang cenderung kontekstual -sebagai kelompok mayoritas-, baik secara verbal maupun nonverbal. Hal ini dapat terlihat dari caption yang tampak dari berbagai meme hadis yang bertebaran di media sosial termasuk yang tertera di beberapa contoh di atas. Pada gambar meme pertama (1) tertulis: "Muslim keren itu nggak isbal. Kasih jarak segini (Panah menujuk batasan bawah ujung celana);" pada gambar meme kedua (2) tertulis: "Ngapain malu? Mereka yang celananya sepaha aja gak malu, ini cuma dinaikin dikit..." pada gambar yang ketiga (3) tertulis: "Keterangan: Bukan apa-apa sih Sob.. Celana ane kaya gini soalnya ane ngeri masuk neraka aja sob.." pada gambar yang keempat (4) tertulis: "Apa yang membuatmu khawatir dari sekedar cibiran "radikal, teroris dsb," jika bercelana cinkrang justru menghindarkanmu dari siksa Neraka, mendapat pahala serta terlihat lebih fashionable." Pada gambar keenam (6) tertulis: "Isbal tapi ngaku tidak sombong? Anda bohong!! Padahal isbal merupakan bentuk kesombongan." Pada gambar ketujuh (7) tertulis: "Celana cingkrang. Ini bukan celana teroris, kebanjiran, ormas. Melainkan ini adalah perintah Allah dan rasul-Nya." sedangkan yang terakhir terdapat pada gambar yang kedelapan (8): “ Di saat cowok melaksanakan perintah Rasulullah dengan celana di atas mata kaki. Kata mereka: GA GAUL, KAMPUNGAN, KATRO, GA MODERN, KUNO, UDIK, KOLOT, NORAK,....."

Beberapa caption yang ada mengindikasikan realitas sosial yang dihadapi oleh kelompok tekstualis, yaitu resistensi dari kelompok yang berbeda dengan mereka. Dalam hal ini, terdapat beberapa model resistensi yang diberikan masyarakat terhadap eksistensi kelompok tekstualis yang pada gilirannya menggiring mereka melakukan aktualisasi diri melalui sebuah meme sebagai bentuk retaliasi, antara lain: pertama, resistensi atas pemahaman hadis tentang isbāl. Sebagaimana sudah disinggung di muka, bahwa menurut mayoritas ulama, larangan isbāl hanya berlaku apabila disertai perasaan sombong. Selain mengacu pada riwayat kisah tentang Abū Bakar di atas, terdapat banyak teks hadis tentang larangan isbāl yang beriringan dengan kata sombong di dalamnya. Sebagai contoh (al-Sijistānī, t.th, IV: 60, 4094):

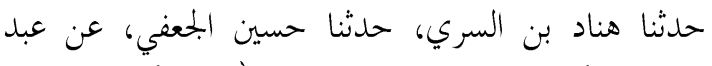

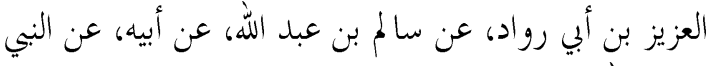

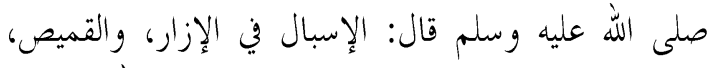

$$
\begin{aligned}
& \text { والعمامة، من جر منها شيئا خيلاء، لم ينظر الله إليه يوم } \\
& \text { القيامة. }
\end{aligned}
$$

Menceritakan kepada kami Hannād ibn al-Sariy, menceritakan kepada kami Husain al-Ju'fī, dari 'Abd al'Azīz ibn Abī Rawwād, dari Sālim, dari ayahnya, dari Nabi Saw., beliau bersabda: isbāl berada dalam sarung, kemeja dan serban, barangsiapa menjulurkannya dengan perasaan sombong, maka Allah tidak akan melihatnya pada hari kiamat.

Demikian pula riwayat (al-Bukhārī, 1422 H, VII: 141, 5788):

$$
\begin{aligned}
& \text { حلثنا عبد الله بن يوسف، أخبرنا مالك، عن أبي الزناد، عن }
\end{aligned}
$$

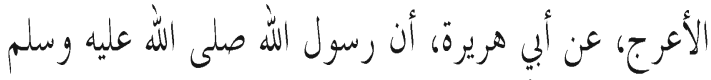

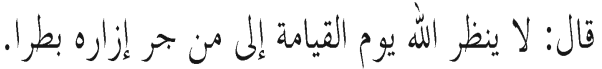

Menceritakan kepada kami 'Abd Allāh ibn Yūsuf, mengabarkan kepada kami Mālik, dari Abū alZinād, dari al-A'rāj, dari Abū Hurairah bahwasanya Rasulullah Saw. bersabda: Allah tidak melihat pada orang yang menjulurkan sarungnya karena sombong. 
Dalam kehidupan sosial, tampaknya argumen itulah yang mereka dapatkan dari kelompok yang berbeda; tidak mengherankan apabila kemudian mereka melakukan retaliasi dengan menulis, "Isbal tapi ngaku tidak sombong? Anda bohong!! Padahal isbal merupakan bentuk kesombongan." Pernyataan ini mengacu pada potongan teks hadis Nabi yang berbunyi (al-Sijistānī, t.th, IV: 60, 4084):

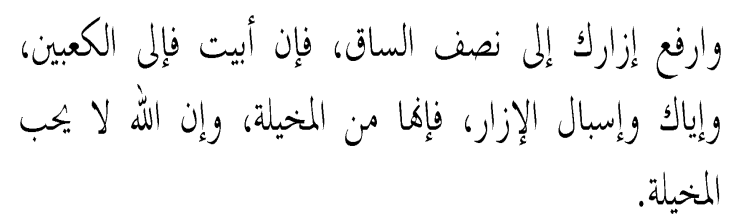

Dan angkatlah kainmu sampai tengah betis. Jika tidak, boleh sampai mata kaki. Jauhilah olehmu menjulurkan (isbāl) kain karena ia termasuk kesombongan dan sesungguhnya Allah tidak menyukai kesombongan.

Kedua, adanya resistensi dari masyarakat umum atau kelompok lain atas penampilan yang diasosiakan secara tidak baik, seperti teroris, kebanjiran, identik dengan pakaian ormas tertentu dan sebagainya. Mengenai hal ini, yang dilakukan oleh produser meme adalah dengan menegaskan bahwa mereka yang mengenakan celana cingkrang bukan teroris, bukan karena kebanjiran dan bukan karena pakaian organisasi masyarakat (Ormas) tertentu. Sama dengan saat merespon kategori resistensi yang pertama, untuk kategori yang kedua ini pun kelompok tekstualis ini cenderung berlindung di balik teks hadis yang dirasa meneguhkan sikap keberagamaan mereka.

\section{Meme Hadis Celana Cingkrang: Revitalisasi Wacana Hadis tentang Is $\bar{a} \bar{l}$ dan Reaktualisasi Kelompok Tekstualis}

Memperhatikan uraian sebelumnya, jelas bahwa pada dasarnya diskusi tentang isbāl sudah menjadi diskusi vital di kalangan ulama, jauh sebelum adanya media sosial. Dengan kata lain, sebenarnya persoalan isbāl merupakan isu lama yang kemudian mencuat kembali ke permukaan, dalam hal ini, melalui meme hadis celana cingkrang yang memberikan kesan sangat populis. Terbukti dengan banyaknya meme yang mengusung pemahaman yang tunggal bahwa isbāl adalah haram baik disertai rasa sombong maupun tidak. Bahkan tidak jarang memberikan kesan bahwa itu adalah satu-satunya pemahaman yang sesuai dan seharunya hadis tentang isbāl dipahami demikian. Populasi meme terkait sampai mengalahkan populasi meme yang memuat pesan yang sama dengan pemahaman mayoritas ulama yang cenderung kontekstual.

Dengan demikian ada indikasi upaya revitalisasi yang dilakukan oleh pihak tertentu, dalam hal ini adalah kelompok tekstualis. Menurut Saifuddin Zuhri Qudsy fenomena tersebut dapat mendominasi sehingga lambat laun memengaruhi cara berpikir umat Islam. Lebih jauh ia bisa menjadi media efektif dalam rangka menyebarkan sebuah ideologi (Qudsy, 2017). Sebagai implikasi, fenomena ini pun menjadi upaya mereka melakukan reaktualisasi dengan cara memunculkan kembali wacana keagamaan yang sudah tidak banyak dipersoalkan.

Lebih dari itu, temuan ini sekaligus menguatkan temuan para peneliti sebelumnya bahwa eksistensi meme tidak pernah bebas kepentingan atau sama sekali tidak mencerminkan realitas tertentu. M. Wildan melalui artikelnya yang berjudul, "Dialektika Kebahasaan Meme pada Media Sosial: Tinjauan Sosiolinguistik," menegaskan bahwa dialektika kebahasaan meme pada dasarnya merupakan bentuk imitasi dari kejadian nyata di lingkungan sosial masyarakat (Wildan, 2016: 42). Sandy Allifinsyah juga menemukan bahwa 
meme merupakan artefak digital yang bisa menunjukkan konteks dan situasi sosial, politik serta sikap masyarakat pada situasi tertentu (Allifinsyah, 2016: 163).

Namun, memang harus diakui, terdapat titik penting yang menjadi pembeda antara temuan penulis dengan temuan para penulis terdahulu; dalam konteks eksistensi meme hadis celana cingkrang, terdapat beberapa realitas sosial yang bisa dilihat secara nyata, mulai dari kesenjangan, konflik hingga keberagaman dalam keberagamaan, khususnya di Indonesia. Titik pembeda ini dapat dipahami, selain karena fokus kajian dan metodologi yang digunakan berbeda, juga harus diakui bahwa kajiankajian terdahulu memberikan kesan mengenyampingkan pembahasan yang secara nyata sebenanrya menjadi isu sentral karena selalu disangkutpautkan dengan perilaku keberagamaan.

Menjamurnya paham dan kelompok tekstualis di tengah keberagaman keberagamaan di Indonesia tidak lepas dari kenyataan bahwa pemahaman tekstual terhadap teks-teks keagamaan masih memiliki ruang penerimaan di tengah masyarakat. Beriringan dengan kondisi politik yang semakin memungkinkan untuk menyampaikan sebuah pendapat dengan batasan-batasan tertentu. Khususnya pasca Orde Baru. Ditambah lagi dengan kenyataan lain bahwa seiring perkembangan teknologi informasi, berbagai hal tanpa terkecuali informasi seputar literatur keagamaan sangat mudah diakses oleh siapa pun dan di mana pun. Apalagi dengan menjamurnya aplikasi dan program (software) yang berisi berbagai literatur keagamaan, baik hadis, al-Qur'an, fikih, tauhid dan sebagainya, sangat memungkinkan untuk dicopy-paste dan kemudian disebarluaskan. Proses copypaste ini pun bisa dari situs atau website tertentu yang dianggap relevan dan sesuai dengan pemahaman mereka khususnya situs atau website yang berasal dari para ulama Salafi di Timur Tengah seperti Ibn Baz dan sebagainya atau yang berafiliasi dengan mereka.

\section{SIMPULAN}

Berdasarkan pada paparan yang relatif singkat di atas, dapat disimpulkan bahwa setidaknya terdapat dua alasan utama yang berada di balik fenomena meme hadis celaan cingkrang yang bertebaran di media sosial: pertama, bahwa ia merupakan media peneguhan identitas diri kelompok tektualis, skriptualis atau literalis. Peneguhan tersebut diekspresikan dengna cara melakukan identifikasi diri sebagai kelompok yang mengikuti sunah Nabi Saw. meski pun pada dasarnya hanya berangkat dari sebuah pemahaman tekstual terhadap teks-teks agama, khususnya teks hadis seputar isbāl. Peneguhan identitas tersebut dilakukan karena adanya kontestasi ideologis dengan penganut paham keagamaan yang berbeda, khususnya penganut paham yang cenderung kontekstual terkait hadis-hadis tentang isbāl.

Kedua, sebagai bentuk retaliasi kelompok tekstualis -sebagai minoritasterhadap ragam resistensi masyarakat yang cenderung kontekstual -sebagai kelompok mayoritas-, baik secara verbal maupun nonverbal. Dalam hal ini resistensi masyarakat muncul dengan dua model: (1) pemahaman yang sesuai dengan mayoritas ulama yang cenderung tidak memahami hadis larangan isbāl secara tekstual, dan (2) celana cingkrang diasosiakan secara tidak baik, seperti teroris, kebanjiran, identik dengan pakaian ormas tertentu dan sebagainya. Dalam merespons dua bentuk resistensi ini, mereka tampak berlindung di balik teks hadis yang dirasa meneguhkan sikap keberagamaan mereka. 


\section{UCAPAN TERIMAKASIH}

Artikel ini sudah dipresentasika pada Annual International Conference on Islamic Studies (AICIS) ke-17, 2017. Terimakasih yang sebesar-besarnya pada semua pihak yang ikut berkontribusi, memberi masukan dan sebagainya. Terimakasih juga sudah memberikan kebebasan pada penulis untuk menerbitkannya di jurnal ilmiah. Terakhir, terima kasih penulis tujukan kepada Mitra Bestari dan Pengelola Jurnal Harmoni yang telah memberikan catatan dan saran untuk perbaikan tulisan ini, hingga bisa diterbitkan pada Jurnal Harmoni edisi kali ini.

\section{DAFTAR PUSTAKA}

\section{Buku dan Jurnal:}

'Asqalānī, Abū al-Faḍ l Ah mad ibn Hajar al-. Fatḥ al-Bārī Syarh Ṣ aḥ ịh al-Bukhārī. Beirut: Dār al-Ma'rifat, 1379 H.

Abu Nawas, Muh. Zuhri. "Teknik Interpretasi Tekstual dan Kontekstual," Jurnal alAsas, Vol. III, No. 1, April 2015.

Abū Zaid, Bakar 'Abd Allāh. Hadd al-Ś aub wa al-Uzrah wa Tah rīm al-Isbāl wa Liba.s al-Syuhrah. Arab Saudi: Dār al-'Āṣ imah, 1416.

Allifinsyah, Sandy. "Kaum Muda, Meme, dan Demokrasi Digital di Indonesia," Jurnal Ilmu Komunikasi, Volume 13, Nomor 2, Desember 2016.

Amran, "Studi Kritik hadis tentang Isbal. Antara budaya dan kesombongan)," Jurnal An-Nahdhah, Vol 10, No 2. 2016).

Asriaty, "Tekstualisme Pemikiran Hukum Islam. Sebuah Kritik)," Mazahib: Jurnal Pemikiran Hukum Islam, Volume 11, Nomor 1, Juni 2013.

Aw, Liliek Hanna. "Memahami Makna Hadis secara Tekstual dan Kontekstual," Ulumununa: Jurnal Studi Keislaman, Volume XV Nomor 2 Desember 2011.

Bassām, 'Abd Allāh al-. Tauḍ ịh al-Aḥ kām min Bulūg al-Marām. Jeddah: Dār alQiblah li al-S|aqāfah al-Islāmiyyah, 1992.

Bukhārī, Muḥ ammad ibn Isma'īl al-. Ș ạ̣ ịh al-Bukhārī, ed. Muḥ ammad Zuhair alNas ir. Ttp: Dār T auq al-Najāh , 1422 H.

Cindy, Natasha. "Representasi Meme Jomblo dalam Situs Jejaring Sosial Twitter. Analisis Semiotika Roland Barthes)," KOM FISIP Vol 3 No. 2, Oktober 2016.

Hukmi, Risalatul. “"Meme' Theory:. Evolusi Kebudayaan menurut Richard Dawkins)," Paper Fakultas Filsafat, Universitas Gadjah Mada, 6-8;

Ibn Manz ūr, Jamāl al-Dīn Abū al-Faḍ l. Lisān al-'Arab. Beirut: Dār Ṣ ādir, 1414 H.

Nasir, Muhammad. "Kontroversi Hadis-Hadis Tentang Isbal (Telaah Kritis Sanad dan Matan Hadis serta Metode Penyelesainnya)," Jurnal Farabi Vol. 10 No. 1 Juni 2013, 82. 
Nasir, Muhammad. "Kontroversi Hadis-Hadis Tentang Isbal. Telaah Kritis Sanad dan Matan Hadis serta Metode Penyelesainnya)," Jurnal Farabi Vol. 10 No. 1 Juni 2013.

Nugraha, Aditya, Ratih Hasanah Sudrajat, Berlian Primadani Satria Putri, "Fenomena Meme di Media Sosial: Studi Etnografi Virtual Posting Meme Pada Pengguna Media Sosial Instagram,” Jurnal Sosioteknologi, Vol. 14, No 3, Desember 2015.

Pusanti, Rosa Redia dan Haryanto, "Representasi Kritik dalam Meme Politik. Studi Semiotika Meme Politik dalam Masa Pemilu 2014 pada Jejaring Sosial "Path" sebagai Media Kritik di Era Siber),” Jurnal Kommas, 2014.

Putri, Wilga Secsio Ratsja, R. Nunung Nurwati, \& Meilanny Budiarti S., "Pengaruh Media Sosial Terhadap Perilaku Remaja," PROSIDING KS: RISET \& PKM, Vol. 3, No. 1, 50.

Rachman, Rio Febriannur. "Menelaah Riuh Budaya Masyarakat di Dunia Maya," dalam Jurnal Studi Komunikasi, Vvol 1, No. 2, Juli, 2017, 209.

Ș an'ānī, Muḥ ammad al-. Istīfā' al-Aqwāl fì Taḥ rīm al-Isbāl, ed. 'Aqīl al-Maqtirī. San'a: Maktabah Dār al-Quds, 1992.

Sijistānī, Abū Dāwūd al-. Sunan Abī Dāwūd, ed. Muh ammad Muḥ yī 'Abd al-Hamīd. Bairūt: al-Maktabah al-'Asriyyah, t.th.

Wadipalapa, Rendy Pahrun. "Meme Culture \& Komedi-Satire Politik: Kontestasi Pemilihan Presiden dalam Media Baru," Jurnal Ilmu Komunikasi, Volume 12, Nomor 1, Juni 2015.

Wildan, M. "Dialektika Kebahasaan Meme pada Media Sosial: Tinjauan Sosiolinguistik,"Proceeding IICLLTLC-2 2016.

\section{Internet:}

Hafizhul L, Iqbal. "Fenomena Meme "Dosen Gaib" di Media Sosial," dalam http://fisipersui.org/fenomena-meme-dosen-gaib-di-media-sosial/, diakses pada 21 Juli 2017, pukul 8:49 WIB.

Indrajit, Richardus Eko. "Relasi Dunia Nyata dan Dunia Maya dalam Konteks Menjaga Keamanan Internet," dalam https://idsirtii.or.id/doc/IDSIRTII-Artikel-dunia_maya_dan_nyata.pdf, diakses pada 22 Desember 2017, pukul 22:30 WIB.

Qudsy, Saifuddin Zuhri. "Meme Hadis Celana Cingkrang: Menciptakan Budaya Tanding," http://jalandamai.org/meme-hadis-celana-cingkrang-menciptakanbudaya-tanding.html, diakses pada 21 Juli 2017, pukul 20:51 WIB.

"Mazhab al-Jumhūr fī Mas'alah Isbāl al-sं iyāb," dalam https://islamqa.info/ar/102260, diakses pada 29 Agustus 2017 pukul: 15:08 WIB.

http://mui-jakartatimur.or.id/hukum-isbal/, diakses pada 27 Agustus 2017, pukul: 12:49 WIB. 
http://www.imgrum.co/media/1586346573489872274_5894126183, diakses pada 27 Agustus 2017, pukul: 13:17 WIB.

http://www.imgrum.co/media/1586827991073449837_2275952385, diakses pada 27 Agustus 2017, pukul: 12:49 WIB.

http://www.imgrum.org/media/1271019603685551084_305538849, diakses pada 27 Agustus 2017, pukul: 13:17 WIB.

http://www.imgrum.org/media/1294891373153483009_1549997496, diakses pada 27 Agustus 2017, pukul: 13:17 WIB.

http://www.sugiheling.net/2017/03/hukum-isbal-dalam-islam.html, diakses pada 27 Agustus 2017, pukul: 13:17 WIB.

https:/plus.google.com/photos/116281430711738132204/albums/60512522322282282 57/6051252234822405554, diakses pada 27 Agustus 2017, pukul: 13:17 WIB.

https://scontent-sea1-1.cdninstagram.com/t51.2885-

15/s750x750/sh0.08/e35/14156652_163923740712520_78978316_n.jpg?ig_cac he_key=MTMyOTE1NTM2NTg1Mzc3MDIyOA\%3D\%3D.2, diakases pada 27 Agustus 2017, pukul: 13:17 WIB. 